\title{
Investigation of Nitrate Groundwater Quality in Sidoarum Village, Godean District, Sleman Regency, Special Region of Yogyakarta
}

\author{
Herwin Lukito $^{1)}$, Ekha Yogafanny ${ }^{1 a)}$, Suharwanto ${ }^{1)}$, Sektiana Uyun Azizah ${ }^{1)}$, Vindy Fadia Utama ${ }^{1)}$, \\ Novia Devi Safitri ${ }^{1)}$ \\ ${ }^{1)}$ Teknik Lingkungan, Fakultas Teknologi Mineral, UPN "Veteran” Yogyakarta \\ Jl. SWK Lingkar Timur No. 104, Depok, Sleman, Daerah Istimewa Yogyakarta \\ ${ }^{a}$ Correspondence e-mail: ekha.yogafanny@upnyk.ac.id
}

\begin{abstract}
Sidoarum Village, Godean District, Sleman Regency, Special Region of Yogyakarta become one of the developing areas for getting influenced by Yogyakarta City centre which is only 8 kilometres away. Population growth has occurred from 2010 to 2019, which has led to land-use changes from agricultural areas to residential areas. Land-use change, population growth, incorrect space use, excessive use of fertilizers, agricultural activities, and industrial waste disposal affect groundwater quality resources, especially Nitrate $\left(\mathrm{NO}_{3}\right)$ compounds. This research was aimed to determine the distribution of groundwater quality based on nitrate parameters and to analyze the relationship between land use changing and nitrate concentrations in groundwater. This mixed-method research used the survey and mapping methods to collect the data. The analysis was conducted by laboratory tests and spatial analysis method using ArcGIS software. The sampling of groundwater was carried out by the purposive sampling method based on differences in land use. The results indicated that most of the groundwater in Sidoarum Village had been contaminated by Nitrate due to activity in agricultural areas like intense fertilizer application and farming on a household scale in densely populated areas, especially with the lousy sanitation system. The distribution of nitrate contaminated groundwater was correlated to the types of land use. Land-use change monitoring is needed, especially from agricultural areas to residential areas due to excessive population growth.
\end{abstract}

Keywords: Groundwater quality, Nitrate $\left(\mathrm{NO}_{3}\right)$, agriculture area, residential area

\section{INTRODUCTION}

Located close to the city centre of Yogyakarta, Sidoarum Village has been affected by the urban development of Yogyakarta. This trend turned the Sidoarum village into a suburban area characterized by high population growth and economic development. The increase in population will lead to a rise in infrastructure and all aspects of life, including the need for groundwater (Widiyanto et al., 2015). Based on UNFPA Village Projection Data from BPS Sleman 2020, the population growth in Sidoarum Village from 2010 to 2019, which initially amounted to 16,986 people to 20,673 people, has been affecting the land-use changes from agricultural areas to the residential area. The land-use type in Sidoarum Village consists of residential areas and agriculture areas which has undergone a difference in the area. In 2012, the areas of agricultural land were $202 \mathrm{Ha}$ that has changed into $148 \mathrm{Ha}$ in 2020 . The same pattern happened in the settlement areas that was $160 \mathrm{Ha}$ in 2012 transformed into $226 \mathrm{Ha}$ in 2020.

Many activities in the agricultural land, settlements, shrubs and many industrial sectors affect hydrological conditions, both surface water and groundwater (Agustiningsih et al., 2012). The concentration of Nitrate can be used as an indicator of groundwater pollution in the area caused by the unsuitable land-use changes, poor drainage, and sanitation system. Water quality and runoff water volume in the hydrological system of an area are influenced factors of changes in land use and land management (Huang et al., 2013). Land-use changes from the green open spaces to agricultural and residential areas and all human activities, including agricultural and industrial activities, will produce residual activities called anthropogenic. Land use analysis can determine changes in the water quality resources in the hydrological cycle which are closely related to spatial use or land-use changes (Narany et al., 2017).

According to Anna (1993), a dug well groundwater has been contaminated, such as E. Coli bacteria, detergents, nitrates, and other organic and inorganic compounds. Drinking water must meet the drinking water quality standard in terms of its physical, chemical, and biological conditions. Not following the regulations will cause various diseases such as diarrhea, dysentery, and others. In recent years the quality of groundwater worldwide has decreased, which is influenced by nitrates, which are organic compounds that become pollutants from the remaining products of human activities (Amarine et al., 2020). Agricultural area, which is a land designation with wide coverage, can contribute to organic compound pollutants. One of them is Nitrate obtained from excessive use of pesticides and fertilizers (Anna, 1993). 
Nitrate is an easily dissolved compound transported from the source into the groundwater system (Narany et al., 2017). Nitrate is an inorganic chemical compound that enters the groundwater system through surface activities (Marghade, 2020). The $\mathrm{N}_{2}$ compound is nitrate content in raw water contained in agricultural fertilizers (Dohare, 2014). Nitrogen $\left(\mathrm{N}_{2}\right)$ contained in fertilizers is used to increase crop productivity. However, excessive use can cause degradation of groundwater quality and contamination of drinking water sources which pose an immediate risk to human health (Wick, 2012). The possibility of nitrate contamination can be through anthropogenic activities, washing of landfills, livestock waste, domestic and industrial waste (Marghade, 2020). A significant increase in Nitrate concentration every year occurred in the agriculture and residential wells (Narany et al., 2017).

The nitrate concentration in groundwater is derived from unsuitable land utilization and poor sanitation. The daily human activities with poor sanitation and drainage system and inappropriate use of fertilizer will pollute the groundwater that can reduce water quality (Agustiningsih et al., 2012). Excessive use of fertilizers, rapid population growth, and intensive agriculture activities will negatively impact groundwater contamination and could even worsen if the waste irrigation system is poor (Bawa \& Dwivedi, 2019). The existence of organic/inorganic compounds and bacteria in groundwater can potentially cause health problems (Saparuddin, 2010).

Anthropogenic chemical compounds discharged into the environment can become pollutants in groundwater systems as the main supply of clean water and drinking water in Sidoarum Village. Some health problems caused by consuming groundwater as drinking water that contaminated by Nitrate are a decrease in the oxygen capacity in blood, methemoglobinemia, baby blue syndrome, hypotension, stomach cramps, vomiting, indigestion, and even death threats from methemoglobinemia symptoms (Husaini et al., 2020).

The groundwater quality mapping is needed to minimize the health impacts that may arise from the consumption of polluted groundwater. Sidoarum Village, as one of the villages with a dense population, rapid land-use changes, and various human activities, is why this village requires a study of groundwater quality. One of the parameters that can reflect multiple conditions of groundwater quality and the environment, in general, is Nitrate. Based on the description above, this study aims to determine the distribution of groundwater quality based on nitrate parameters and to analyze the relationship between land use and nitrate concentration in groundwater in Sidoarum Village, Godean District, Sleman Regency, D.I Yogyakarta.

\section{METHODS}

The study area was located in Sidoarum Village, Godean District, Sleman Regency, Special Region of Yogyakarta, located on UTM coordinates $\mathrm{X}=423076 \mathrm{mT}-42581 \mathrm{mT}$ and $\mathrm{Y}=9138318 \mathrm{mU}-9142432 \mathrm{mU}$ that presented in Figure 1. The researcher conducted this study from June until July 2020.

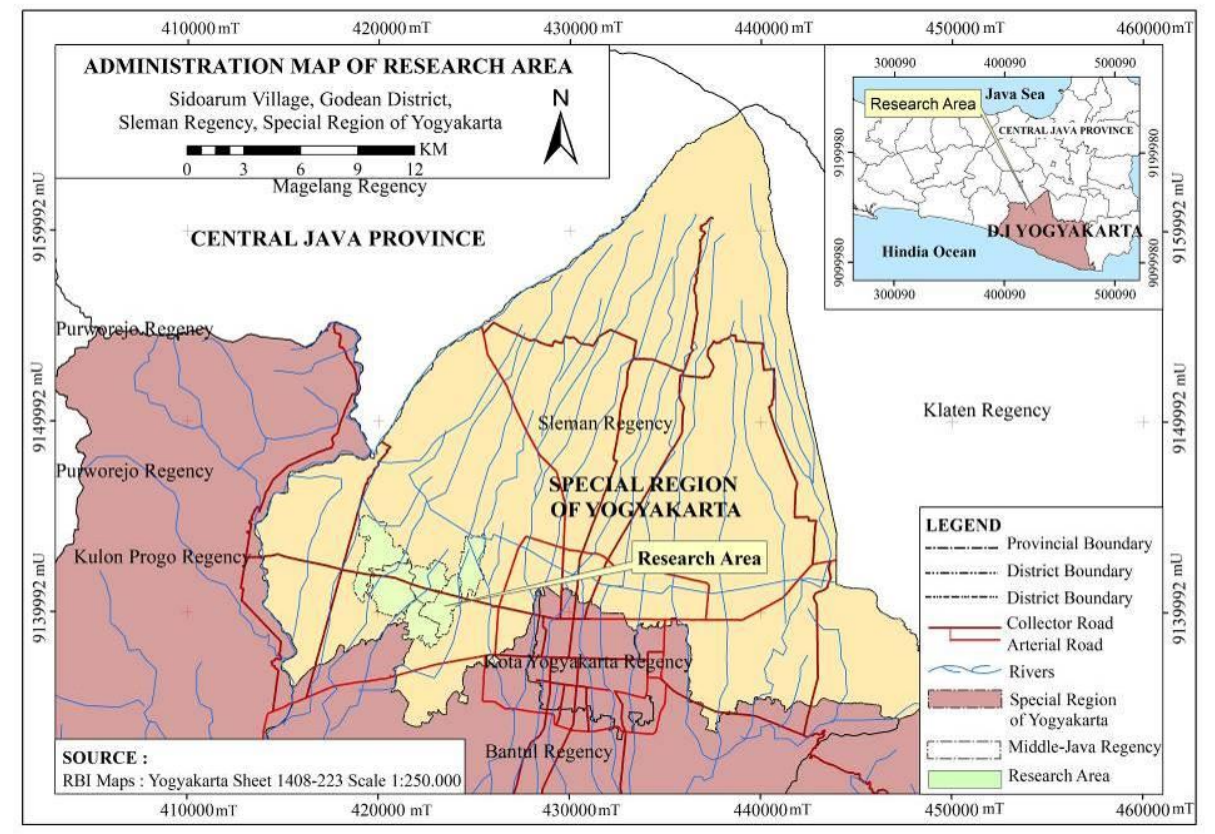

Figure 1. Administration Map of Sidoarum Village.

The research method was qualitative based on the nitrate concentration of groundwater. The data acquisition was conducted based on the field survey and mapping for the primary data (nitrate concentration, existing land use condition, etc.) and institutional study for the secondary data (base maps, population number, etc.). The tools used were one-litre 
sample bottles, GPS, and a camera for documentation. Groundwater sampling was carried out using a purposive sampling method based on two different types of land use (agriculture and non-agriculture area/residential area) and the availability of shallow groundwater wells in the study area that can be seen in Figure 2. The groundwater sample was tested in the laboratory to determine the nitrate concentration. All data were spatially analyzed based on the thematic map on the scale of 1:13.000. The spatial analysis using ArcGIS Software was used to know and analyze the distribution of nitrates and the correlation between groundwater quality and land use in the study area.

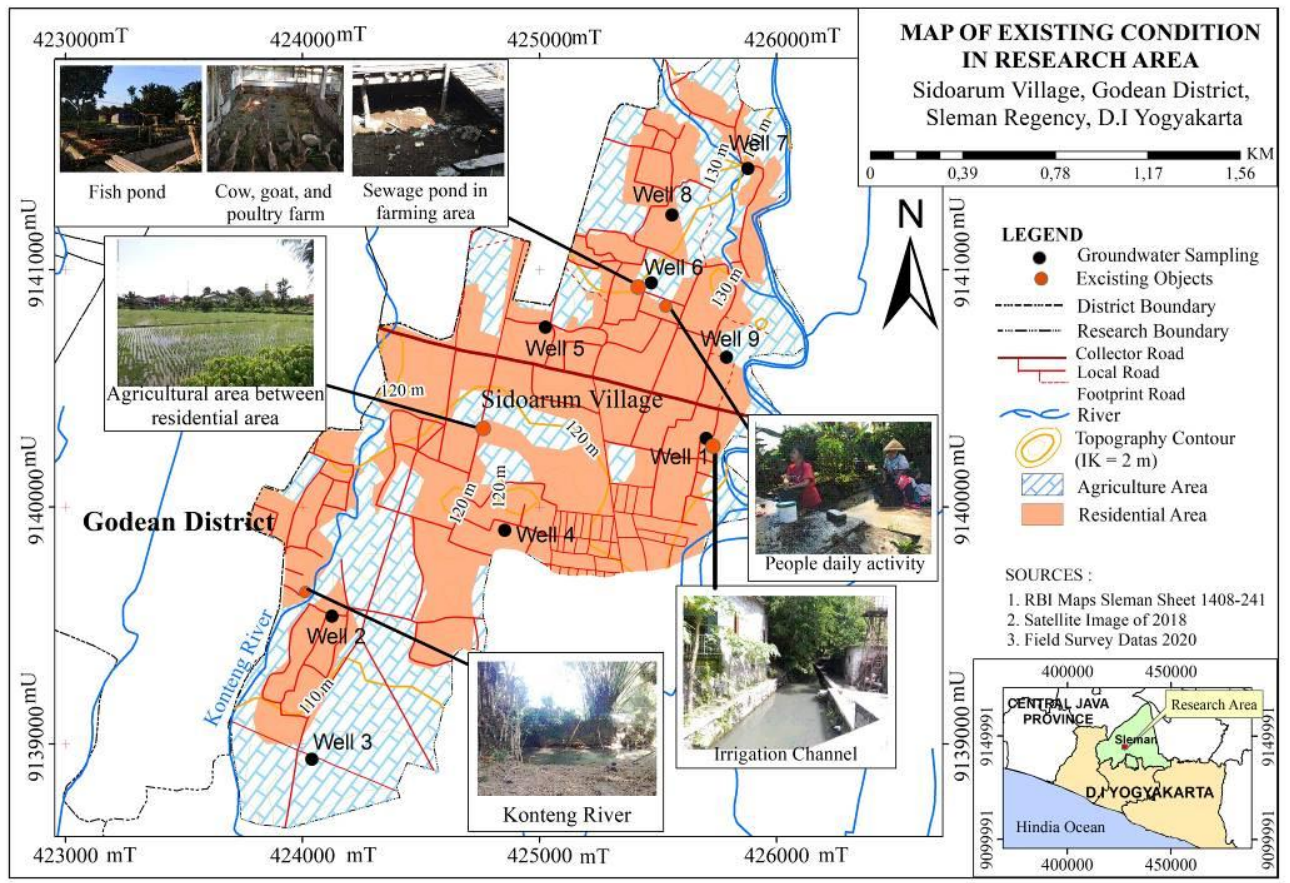

Figure 2. Map of Existing Condition

\section{RESULTS AND DISCUSSION}

The concentration of Nitrate in groundwater samples was analyzed in the laboratory of BBTKLPP Yogyakarta. The use of groundwater as drinking water by the people of Sidoarum Village requires its water quality to meet the drinking water standard of Class I Government Regulation Number 82 the year 2001. The maximum concentration of Nitrate is 10 $\mathrm{mg} / \mathrm{L}$. Table 1 represents the results of a laboratory test of 9 groundwater samples. Of nine groundwater samples, six had a nitrate value greater than $10 \mathrm{mg} / \mathrm{L}$, and three were below the quality standard. From the laboratory test results, the highest nitrate concentration existed in Well 1, reaching about $82.53 \mathrm{mg} / \mathrm{L}$, and the lowest concentration of Nitrate was in Well 3, about lower than $0,04 \mathrm{mg} / \mathrm{L}$.

Table 1. Results of Laboratory Test

\begin{tabular}{lccc}
\hline No & Groundwater Sample & Land use types & $\begin{array}{c}\text { Nitrate Concentration } \\
\left(\mathrm{NO}_{3}\right)(\mathrm{mg} / \mathrm{L})\end{array}$ \\
\hline $\mathbf{1}$ & Well 1 & Residential Area & 82,53 \\
$\mathbf{2}$ & Well 2 & Residential Area & 13,83 \\
$\mathbf{3}$ & Well 3 & Agricultural Area & $<0,04$ \\
$\mathbf{4}$ & Well 4 & Residential Area & 59,24 \\
$\mathbf{5}$ & Well 5 & Residential Area & 1,03 \\
$\mathbf{6}$ & Well 6 & Agricultural Area & 20,62 \\
$\mathbf{7}$ & Well 7 & Agricultural Area & 18,25 \\
$\mathbf{8}$ & Well 8 & Residential Area & 26,42 \\
$\mathbf{9}$ & Well 9 & Agricultural Area & 2,76 \\
\hline
\end{tabular}

Source: Laboratory Results, 2020

Information: exceeded the water quality standard (Class I) 


\subsection{Distribution of Nitrate Contaminated Groundwater}

The nitrates content in consumed drinking water can cause health problems. Understanding the distribution of nitrates in the groundwater will control the groundwater use by people and monitor the land utilization above the groundwater. Amarine et al. (2020) stated that consumption of Nitrate contaminated water might cause health problems. Nitrate can produce nitro amines, which trigger baby blue syndrome and cause stomach cancer and digestive disorders. Nitrates also trigger methemoglobinemia, goitre, and hypertension (Jamaa et al., 2020).

Groundwater sampling points spread across two land uses can be a reference for determining groundwater contamination factors by nitrate compounds that exceed Class I drinking water quality standards. Different land uses show differences in biogeochemical factors to distinguish the chemical content of groundwater in each location in an area (Me nció et al., 2016). Through laboratory testing of nitrate concentration, it is known that nitrate levels that exceed the quality standard are located in agricultural and residential land uses due to several factors that affect the nitrate infiltration process into the groundwater system.

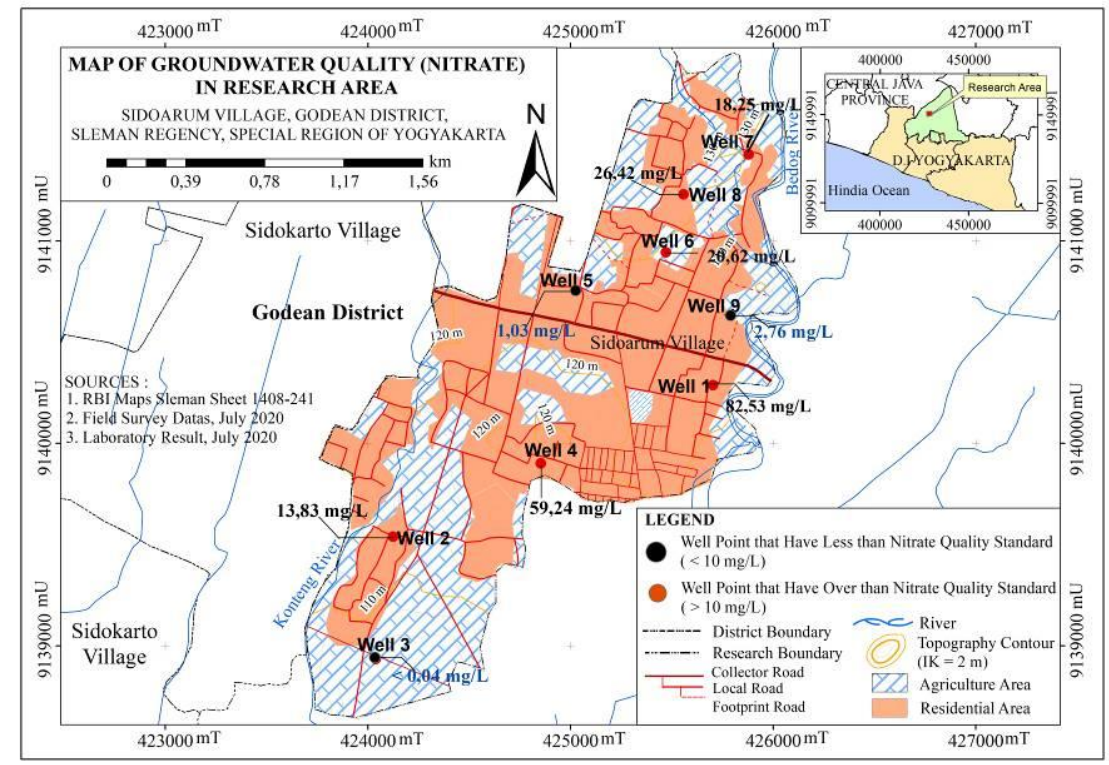

Figure 3. Map of Groundwater Quality (Nitrate)

The Republic of Indonesia regulates the groundwater quality standard for nitrate concentration of $10 \mathrm{mg} / \mathrm{L} \mathrm{maximum}$. Hence, this study divided groundwater into two categories, i.e. $>10 \mathrm{mg} / \mathrm{L}$ and $<10 \mathrm{mg} / \mathrm{L}$. Figure 3 shows the distribution of nitrate quality in the study area. The figure presents that six-well points have a nitrate concentration of more than 10 $\mathrm{mg} / \mathrm{L}$, i.e. well 1, well 2, well 4, well 6 , well 7, and well 8 and three wells points with nitrate concentration less than 10 $\mathrm{mg} / \mathrm{L}$ i.e. well 3, well 5, and well 9. Wellpoint concentrations of more than $10 \mathrm{mg} / \mathrm{L}$ were primarily located in residential areas, i.e. well 1, well 2, well 4, and well 8. Agricultural areas have been confirmed to have contributed to nitrate pollution, such as at well 6 and well 7. The nitrate concentration of well 6 was $20.62 \mathrm{mg} / \mathrm{L}$. Well 6 is located in livestock and fisheries areas, and the northern part of this well is rice fields. The result exceeds the quality standard because livestock waste is disposed of in a waste pond without a base membrane. The remaining manure from livestock or other organic compounds can be easily infiltrated, coupled with pesticides in the rice fields next to the farm. The nitrate concentration of well 7 was $18.25 \mathrm{mg} / \mathrm{L}$. Well 7 is a shrub adjacent to the settlement, containing Nitrate that exceeds the quality standard. This high nitrate concentration can be caused by fertilizers or pesticides and septic tank leakage. This study confirmed Jamaa (2020) study that mentioned that wastewater treatment household scale (septic-tank) and the use of fertilizers in agricultural areas are the primary nitrate contaminants that pollute the environment.

In a densely populated residential area, the same thing happened to well 1 with the highest nitrate concentration, up to $82.53 \mathrm{mg} / \mathrm{L}$. Not far from well 1 there is an irrigation channel near a pig farm which can be a source of nitrate pollutants from the organic livestock waste produced. Other wells point also has nitrate levels of more than $10 \mathrm{mg} / \mathrm{L}$ in residential areas, namely the wells 2,4 , and 8 , which prove that agricultural areas are a source of nitrate pollution in groundwater and the residential area, especially the residential area with the dense settlements. In the middle of residential areas, nitrate contamination occurs through damaged sewers, which have become nitrate contamination in groundwater in urban and suburban areas (Nemčić-Jurec \& Jazbec, 2017).

\subsection{Correlation of Landuse and Nitrate Concentration in Groundwater}


In this study, land uses in Sidoarum Village have been categorized as agricultural and non-agricultural areas or residential areas. The farm area in the study area consisted of rice fields, mixed gardens, livestock and fisheries, and empty land. Higher nitrate pollution mainly occurs in agricultural and shallow groundwater wells because it is more affected by livestock waste runoff and nitrate dilution from fertilizer (Narany et al., 2017). The condition of Nitrate contaminated groundwater on agricultural land can be used as an indicator for pollution risk assessment (Rebolledo et al., 2016). However, based on the results of the groundwater quality test in this study, it turned out that the agriculture area was not the only contributor to nitrate pollution, which affects the quality of groundwater, but also the residential areas.

Infiltration is one of the mechanisms for nitrates to enter the groundwater system. Nitrates included in anions will be infiltrated into the soil and other organic and inorganic substances (Long et al., 2018). Nitrates are entered and reach the aquifer system through gaps or fractures of the rock, filling the voids in the empty soil structure. The groundwater will dilute the nitrate concentration once the Nitrate compound enters and mixes with groundwater. Nitrate dilution occurs a lot during the rainy season, which allows the high rainwater infiltrate to the soil, thus reduce the nitrate concentration. According to that, in the rainy season, the potential of nitrate groundwater pollution reduces.

An increase also follows population growth in the need for clean water. However, population growth also requires land as a place to live, which often leads to land-use conversion from agricultural land to residential land. If not followed by good environmental management, excessive land change will have the potential to cause a decrease in groundwater quality, one of which can be assessed with nitrate parameters (Lerner \& Harris, 2009). Domestic waste in densely populated areas will increase the pollution load in our environment. The densely populated areas will have high nitrate concentrations and E. Coli bacterial contamination (Me nció et al., 2016). The main problem regarding groundwater quality arises from inappropriate land use and control (Lerner \& Harris, 2009).

Figure 4 presents the land use in 2012 and 2020, focusing on agriculture and non-agriculture/ residential areas. The difference between these two land use maps is the area of land use. There has been a change in the type and size of land use in Sidoarum Village. The agriculture area had decreased from $202 \mathrm{Ha}$ in 2012 to $148 \mathrm{Ha}$ in 2020. On the other hand, the non-agriculture area had increased from $160 \mathrm{Ha}$ in 2012 to $226 \mathrm{Ha}$ in 2020. The land-use conversion from agricultural to non-agriculture area appears in the centre and western parts of the study area. It shows the increasing population in Sidoarum Village, thus increasing the demand for residential area development during eight years from 2012 to 2020 .
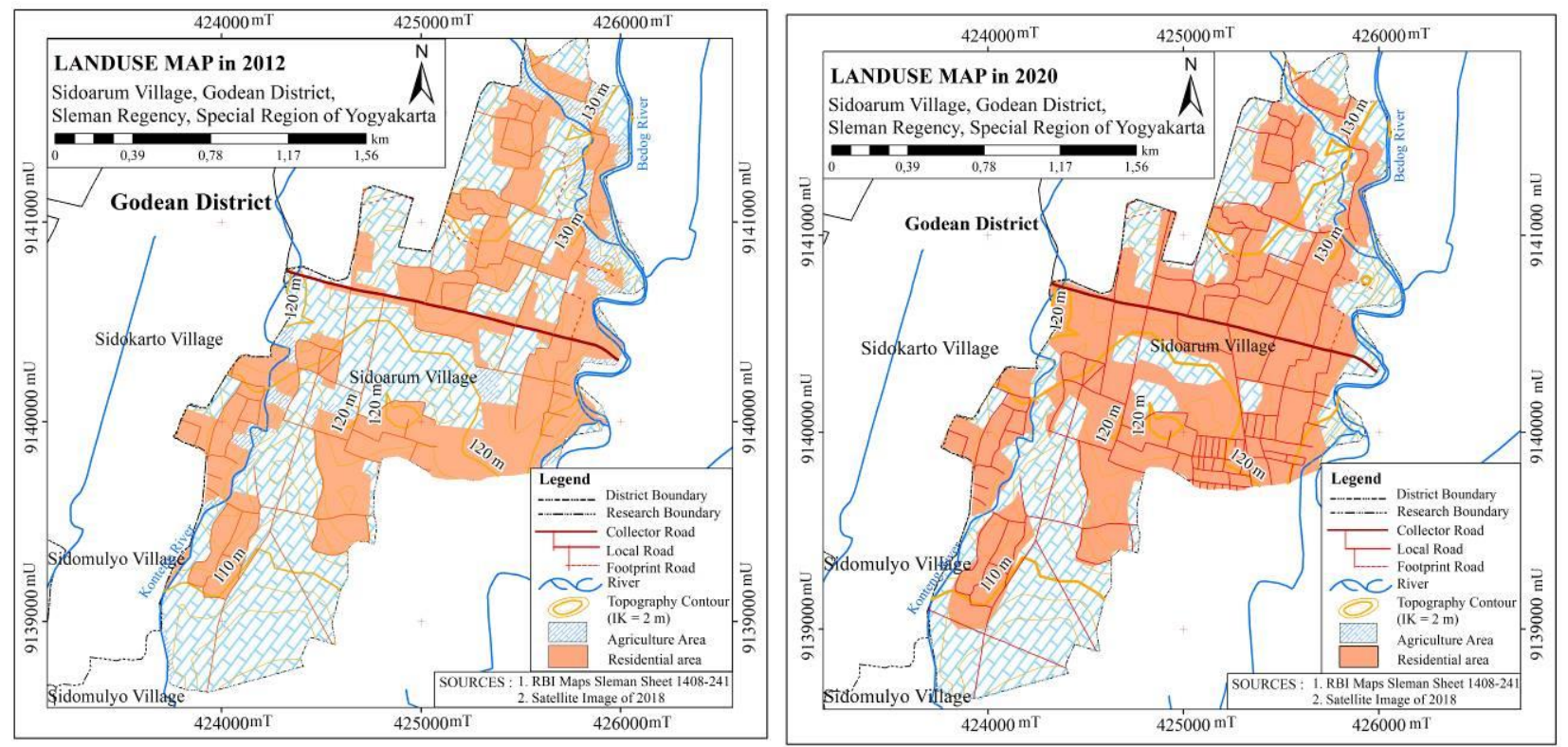

Figure 4. Map of Landuse in 2012 and Map of Landuse in 2020

The results of this study showed that various factors influenced the different nitrate concentrations in groundwater at each point. One of them was the groundwater contamination from agriculture, home-scale industry, and residential activities. Another study also confirmed this phenomenon that urban activities could lead to the contamination of the groundwater (Sajeev et al., 2020). Nitrate and other substances in fertilizers, such as ions, metals, other organic compounds, or even microorganisms from domestic waste that interact with the subsurface environment, pollute the aquifers due to prolonged continuous use (Me nció et al., 2016). 
Smith et al. (2020) stated that residential areas could be a nitrate contributor to the environment associated with septic tank leakage with higher concentrations. So it is necessary to control and monitor good sanitation channels in waste disposal so that it does not become a source of pollution. In this study area, the use of space around or in residential areas can be a non-point source of nitrate pollution. For example, a laundry business disposes of its wastewater containing detergents and other inorganic compounds every day. Moreover, household-scale livestock is one of the contributors to nitrate compounds because the results of manure or livestock manure can be infiltrated and diluted by the rainwater to enter the shallow groundwater system in Sidoarum Village.

In Sidoarum Village, an irrigation channel gets water supply from the Bedog River, which is used to irrigate the community's fish ponds. Being included in the sub-urban category makes people think of directly utilizing the river water, such as washing clothes in the irrigation canal in front of the houses. This activity will also affect surface water quality due to the disposal of domestic wastewater, including detergents. The existence of fish ponds that are not coated with a membrane contributes to the nitrogen infiltration into the aquifer system. This study can conclude that nitrate contamination strongly correlates with land use. Both agriculture and residential land use tended to contribute to the nitrate pollution in the groundwater. Hence, the government and its citizens need to ensure the sanitation system in residential areas and agriculture sustainability.

\section{CONCLUSION AND FURTHER RESEARCH}

The groundwater quality in study area exceeded the Nitrate concentration standard (maximum $10 \mathrm{mg} / \mathrm{L}$ ). Six out of nine wells, i.e. well 1 , well 2 , well 4 , well 6 , well 7 , and well 8 have exceeded the maximum value. Well points with more than $10 \mathrm{mg} / \mathrm{L}$ concentrations were primarily located in residential areas, i.e. well 1 , well 2 , well 4 , and well 8 . Agricultural areas have been confirmed to have contributed to nitrate pollution, such as at well 6 and well 7 .

This study showed that various factors influenced the different nitrate concentrations in groundwater at each point. One of them was the groundwater contamination from agriculture, home-scale industry, and residential activities. Not only agriculture but also residential land use has a contribution to the nitrate pollution in groundwater. The residential areas can be a nitrate contributor to the environment associated with septic tank leakage with higher concentrations, household-scale livestock, and laundry activities. On the other hand, agricultural land use contributes to the nitrate contamination in groundwater due to excessive fertilizer. This study can conclude that nitrate contamination has a strong correlation with land use. Both agriculture and residential land use tended to contribute to the nitrate pollution in the groundwater.

\section{ACKNOWLEDGEMENTS}

This research was funded by the Institute of Research and Community Service (LPPM), University of Pembangunan Nasional "Veteran" Yogyakarta through the scheme of "Penelitian Dasar 2020". We also thank the Department of Environmental Engineering University of Pembangunan Nasional "Veteran" Yogyakarta and those who have assisted in this research.

\section{REFERENCES}

Agustiningsih, D., Sasongko, S. B., \& Sudarno. (2012). Analisis Kualitas Air Dan Strategi Pengendalian Pencemaran Air Sungai Blukar Kabupaten Kendal. Jurnal PRESIPITASI, 9(2), 64-71.

Amarine, M., Lekhlif, B., Sinan, M., El Rharras, A., \& Echaabi, J. (2020). Treatment of nitrate-rich groundwater using electrocoagulation with aluminum anodes. Groundwater for Sustainable Development, 11(September 2019), 100371. https://doi.org/10.1016/j.gsd.2020.100371

Anna, A. N. (1993). Kondisi Air Tanah di Daerah Perkotaan: Problema Antara Kuantitas dan Kualitas Air. Forum Geografi, 7(1), 49. https://doi.org/10.23917/forgeo.v7i1.4797

Bawa, R., \& Dwivedi, P. (2019). Impact of land cover on groundwater quality in the Upper Floridan Aquifer in Florida, United States. Environmental Pollution, 252(3), 1828-1840. https://doi.org/10.1016/j.envpol.2019.06.054

Dohare, D., Deshpande, S., \& Kotiya, A. (2014). Analysis of Ground Water Quality Parameters: A Review. Research Journal of Engineering Sciences, 3(5), 26-31.

Huang, J., Zhan, J., Yan, H., Wu, F., \& Deng, X. (2013). Evaluation of the impacts of land use on water quality: A case study in the Chaohu lake basin. The Scientific World Journal, 2013. https://doi.org/10.1155/2013/329187 
Husaini, D. C., Enriquez, A., Arzu, T., Miranda, K., Mossiah, D., \& Cardinez, C. (2020). Nitrate Levels in Rural Drinking Water in Belize. Journal of Health and Pollution, 10(27), 200904. https://doi.org/10.5696/2156-961410.27.200904

Jamaa, H., El Achheb, A., \& Ibno Namr, K. (2020). Spatial variation of groundwater quality and assessment of water table fluctuations in Plio-Quaternary aquifer formations in Doukkala Plain, Morocco. Groundwater for Sustainable Development, 11(April), 100398. https://doi.org/10.1016/j.gsd.2020.100398

Lerner, D. N., \& Harris, B. (2009). The relationship between land use and groundwater resources and quality. Land Use Policy, 26(SUPPL. 1), 265-273. https://doi.org/10.1016/j.landusepol.2009.09.005

Long, D. T., Pearson, A. L., Voice, T. C., Polanco-Rodríguez, A. G., Sanchez-Rodríguez, E. C., Xagoraraki, I., ConchaValdez, F. G., Puc-Franco, M., Lopez-Cetz, R., \& Rzotkiewicz, A. T. (2018). Influence of rainy season and land use on drinking water quality in a karst landscape, State of Yucatán, Mexico. Applied Geochemistry, 98(March), 265-277. https://doi.org/10.1016/j.apgeochem.2018.09.020

Marghade, D. (2020). Detailed geochemical assessment \& indexing of shallow groundwater resources in metropolitan city of Nagpur (western Maharashtra, India) with potential health risk assessment of Nitrate enriched groundwater for sustainable development. Chemie Der Erde, March, 125627. https://doi.org/10.1016/j.chemer.2020.125627

Me nció, A., Mas-Pla, J., Otero, N., Regàs, O., Boy-Roura, M., Puig, R., Bach, J., Domènech, C., Zamorano, M., Brusi, D., \& Folch, A. (2016). Nitrate pollution of groundwater; all right. . ., but nothing else? Science of the Total Environment, 539, 241-251. https://doi.org/10.1016/j.scitotenv.2015.08.151

Nemčić-Jurec, J., \& Jazbec, A. (2017). Point source pollution and variability of nitrate concentrations in water from shallow aquifers. Applied Water Science, 7(3), 1337-1348. https://doi.org/10.1007/s13201-015-0369-9

Rebolledo, B., Gil, A., Flotats, X., \& Sánchez, J. Á. (2016). Assessment of groundwater vulnerability to nitrates from agricultural sources using a GIS-compatible logic multicriteria model. Journal of Environmental Management, 171, 70-80. https://doi.org/10.1016/j.jenvman.2016.01.041

Sajeev, S., Sekar, S., Kumar, B., Senapathi, V., Chung, S. Y., \& Gopalakrishnan, G. (2020). Variations of water quality deterioration based on GIS techniques in surface and groundwater resources in and around Vembanad Lake, Kerala, India. Chemie Der Erde, March, 125626. https://doi.org/10.1016/j.chemer.2020.125626

Saparuddin. (2010). Pemanfaatan Air Tanah Dangkal sebagai Sumber Air Bersih di Kampus Bumi Bahari Palu. Jurnal SMARTek, 8(2), 143-152.

Sheikhy Narany, T., Aris, A. Z., Sefie, A., \& Keesstra, S. (2017). Detecting and predicting the impact of land-use changes on groundwater quality, a case study in Northern Kelantan, Malaysia. Science of the Total Environment, 599-600, 844-853. https://doi.org/10.1016/j.scitotenv.2017.04.171

Smith, D. N. I., Ortega-Camacho, D., Acosta-González, G., Leal-Bautista, R. M., Fox, W. E., \& Cejudo, E. (2020). A multi-approach assessment of land-use effects on groundwater quality in a karstic aquifer. Heliyon, 6(5). https://doi.org/10.1016/j.heliyon.2020.e03970

Wick, K., Heumesser, C., \& Schmid, E. (2012). Groundwater nitrate contamination: Factors and indicators. Journal of Environmental Management, 111, 178-186. https://doi.org/10.1016/j.jenvman.2012.06.030

Widiyanto, A. F., Yuniarno, S., \& Kuswanto, K. (2015). Polusi Air Tanah Akibat Limbah Industri Dan Limbah Rumah Tangga. Jurnal Kesehatan Masyarakat, 10(2), 246-254. https://doi.org/10.15294/kemas.v10i2.3388 